\title{
NANOTOXICOLOGY FOR SAFE AND SUSTAINABLE NANOTECHNOLOGY
}

\author{
Damjana DROBNE \\ Department of Biology, University of Ljubljana, Ljubljana, Slovenia \\ Received in September 2007 \\ Accepted in October 2007
}

\begin{abstract}
Nanotechnology is the term given to those areas of science and engineering where the phenomena take place at nanoscale dimensions. Nanoparticles are particles with $<100 \mathrm{~nm}$ in one dimension. They have different physical, chemical, electrical and optical properties than those that occur in bulk samples of the same material. Understanding these nanoscale properties and finding ways to engineer new nanomaterials will have a revolutionary impact, from more efficient energy generation and data storage to improved methods for diagnosing and treating diseases. Nanotechnology is poised to become a major factor in the world's economy and part of our everyday lives in the near future. Hundreds of tonnes of nanoparticles already enter the environment annually, but still very little is known of their interactions with biological systems. Recent studies indicate that some nanoparticles are not completely benign to biological and environmental targets. The challenge for toxicologists is to identify key factors that can be used to predict toxicity, permit targeted screening, and allow material scientists to generate new, safer nanoparticles with this structure-toxicity information in mind. The aim of this paper is to summarize some known facts about nanomaterials and discuss future perspectives, regulatory issues and tasks of the emerging branch of toxicology, that is, nanotoxicology.
\end{abstract}

KEY WORDS: electron microscopy, engineered nanomaterials, risk assessment, toxicity testing

Society and economy are likely to benefit from the advantages of nanotechnology in structural engineering, electronics, optics, consumer products, alternative energy, soil and water remediation, medical uses as therapeutics, diagnostic, or drug delivery devices. Physicist Richard P. Feyman was first who talked about the concept of nanoscience in 1959 in his key lecture at the annual meeting of the American Physical Society, and the term nanotechnology was coined in 1974 by a Japanese researcher Nario Taniguchi to mean "precision machining with tolerance of a micrometer or less". It refers to engineering on the molecular and atomic levels.

Despite bright outlooks for the future of nanotechnology, there is an increasing concern that intentional or unintentional human exposure to some types of engineered nanoparticles may lead to significant adverse health effects (1). In addition, there is a concern about environmental contamination and associated effects on the ecosystem, which could have significant societal implications. A growing public debate is emerging on whether the environmental and social costs of nanotechnology outweigh its many benefits (2-5). The questions about the side effects of products of nanotechnologies are pertinent, since the potential for exposure to nanoparticles will increase as the quantity and types of nanoparticles used in the society grow.

As the outcome of all these debates and concerns, a new branch in toxicological research has emerged with the aim to investigate possible harmful effects of exposure to nanomaterials $(6,7)$. Nanotoxicology also encompasses the properties of nanomaterials used in toxicity studies. In addition, nanotoxicology is involved in proposing reliable, robust, and data-assured test protocols for nanomaterials and in human and environmental risk assessment of nanomaterials. 


\section{NANOPARTICLES AND THEIR CHARACTERIZATION}

Nanoparticles range between $1 \mathrm{~nm}$ and $100 \mathrm{~nm}$, which is the same size covered by ambient particles which have been termed "ultrafine" particles. Ultrafine particles and engineered nanoparticles have several characteristics in common, but there are also significant differences. Properties of great toxicological importance are common to both. Both consist of primary particles below $100 \mathrm{~nm}$ in size, which provide a large surface area per unit mass and potentially high surface reactivity. Both tend to form agglomerates when suspended in gases or liquid, depending on the concentration and the chemistry of the suspension medium. Most of the ambient ultrafine particles are generated as heterogeneous aggregates of primary particles (e. g. combustion soot particles), whereas most of the engineered nanoparticles are generated as monodispersed individual particles (e.g. quantum dots, nanosized $\mathrm{TiO}_{2}$, and nanosized $\mathrm{ZnO}$ ), (Figure 1 and 2).

In theory, nanoparticles can be produced from nearly any chemical, however most nanoparticles that are currently in use have been made from transitional metals, silicon, carbon (single-walled carbon annotates, fullerenes), and metal oxides. In many cases engineered nanoparticles exist as nanocrystals.

By making particles of just a few hundred atoms one creates an enormous amount of surface, which

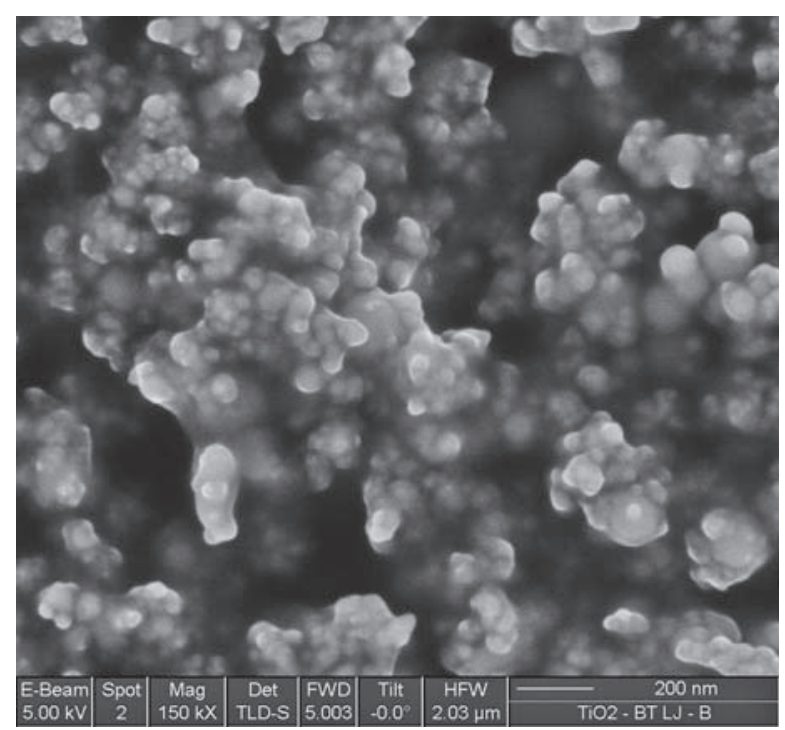

Figure 1. Electron microscopy photos of nanosized titanium dioxide. Photo 1: Scanning electron microscopy (SEM; photo by Tatti, Drobne, Milani 2006, DB Strata 235).

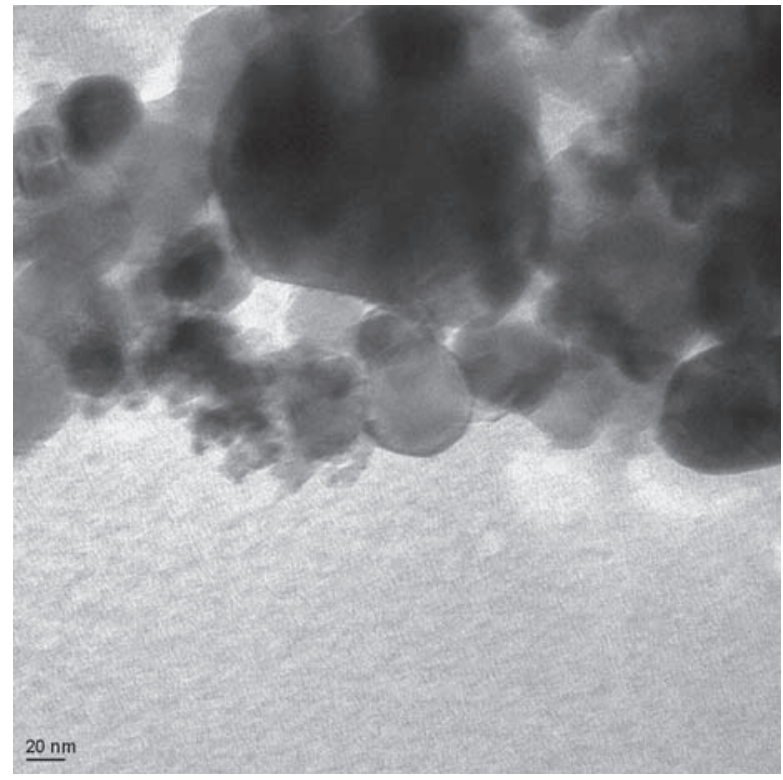

Figure 2 Transmission electron microscopy (TEM; photo by Pipan, Drobne 2006, TEM, Philips CM 100) of nanosized titanium dioxide. SEM and TEM are two methods of choice to investigate particle size, shape, and structure. The resolution of SEM has progressed in recent years and approached that of TEM.

tends to become electrically charged, and thus electro-chemically reactive. Unique electrical and chemical properties make them highly desirable for applications in commercial, medical, environmental and military sectors (8), (Figure 3).

Characterization of a dose of nanomaterials for toxicogical investigation is very complex when compared with chemical toxicants. With the latter, the verification of dose or concentration is usually relatively straightforward. It is based on the characterization of composition and purity of the material tested. But with nanoparticles, apart from bulk chemistry, a variety of other material attributes have to be considered, including size and size distribution, shape, crystallinity, porosity, surface roughness, solubility, surface area, state of dispersion, surface chemistry and many other physico-chemical properties (9). Among all these, four physical parameters are deemed relevant for nanoparticles when assessing their toxicity: particle number, length, surface area, and mass concentration (10).

Transmission electron microscopy (TEM) and scanning electron microscopy (SEM) are gold standards for the evaluation of particle size distribution and shape (Figure 1 and 2) in the context of toxicity screening studies. Both provide specific physicochemical information on engineered nanomaterials. 


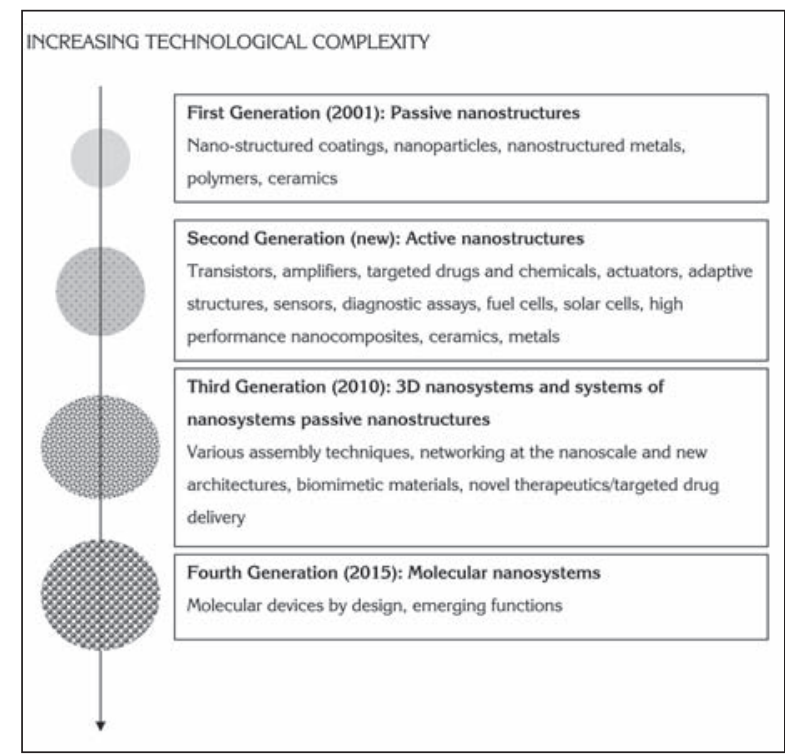

Figure 3 Projected stages of nanotechnology development (adopted by EPA Nanotechnology White Paper, 2007)

\section{INTERACTIONS BETWEEN NANOPARTICLES AND BIOLOGICAL SYSTEMS}

The main questions scientists are currently facing are: what is the mechanism of toxic action of nanoparticles; how does the reactive surface of nanoparticles interact with "wet internal environment inside the body"; and what is the relative contribution of particle size versus particle composition in the overall toxicity of nanoparticles. Definitive answers to all these questions are currently lacking although research is underway in a number of centres.

Although the chemical composition of nanomaterials is known, rearrangements, for example, of carbon into new polymeric structures, or, similarly, the restructuring of metal oxide or crystalline lattice, are worthy of toxicological considerations. The experiences with the different forms of silica and asbestos have taught us that the physical / chemical properties of materials can be very important determinants of the toxicological potential. The very surface area and quantum chemistry effects that the nanosciences are exploring and hope to manipulate, are also known to be important in determining the manner in which biological systems function and interact with the physical world (11).

The multitude of available in vitro studies dealing with the mechanism of nanoparticle uptake in different cell types as well as the few studies on in vivo uptake and nanoparticle distribution in animal models demonstrate that there is no single common uptake mechanism for nanoparticles $(12,13)$.

The upper size limit for the toxicity of nanoparticles (ultrafine particles) is not fully known, but is thought to lie between $65 \mathrm{~nm}$ and $200 \mathrm{~nm}$ (14). In vitro studies performed on cell cultures have confirmed the increased ability of nanoparticles to produce free radicals which can cause cellular damage (15). Generation of reactive oxygen species (ROS) upon exposure of cells to particulate matter is nowadays considered a major contributor to nanoparticle toxicity. The cell membrane, mitochondria, and cell nucleus are considered relevant for possible nanoparticleinduced toxicity (13), (Figure 1). In the light of current knowledge, it seems that the size effect is considerably more important for nanoparticle toxicity than the actual composition of the material. In contrast, in vivo pulmonary inflammation and cytotoxicity studies on rats show that $\mathrm{TiO}_{2}$ toxicity does not depend on particle size and surface area (29).

Over the last five years the number of papers on the ongoing work in nanotoxicology has increased exponentially. However, it is still not possible to draw any common conclusion about how nanoparticles interact with biological systems. In different in vivo and in vitro studies the authors find both dose-dependent and dose-independent response to nanoparticles (17-20). The type of response is obviously related to the measured parameters. In the same study, some measured parameters may be dose-dependent while others may not. It is interesting and worth mentioning that the highest doses do not necessarily provoke the most pronounced response neither in in vitro nor in in vivo studies.

\section{DEVELOPMENT OF TEST PROTOCOLS FOR NANOMATERIALS}

It is not known whether the toxicological assessment of one type and source of nanomaterial will be sufficient to assess the toxicity of the same class/type of nanomaterial produced by a different process. The manufactured materials may also be treated with coatings, or other surface modifications, in order to generate mono-dispersed suspensions that enhance their unique properties. The extent to which surface modifications of intentionally produced nanomaterials affect their toxicity is not known.

In addition, because of the wide variety of properties among nanomaterials, each type can provoke its own 
unique biological response. As a result, different types of nanomaterials should be categorized, characterized and tested separately, although certain concepts of nanotoxicology based on the small size is likely apply to all nanomaterials (7).

The challenge for nanotoxicologists is not to test every variation of a new nanoparticle generated, but instead to identify the key factors that can be used to predict toxicity.

By now, several strategies to screen for the toxicity of nanoparticles have been proposed by various investigators, and discussed in a number of thorough reviews and related documents (5-7, 21-25).

More refined approaches to nanomaterial characterization and toxicological evaluation will emerge with time, but at the moment, the existing test protocols for conventional chemicals are generally recognized as a good starting point. However, these tests have to include additional physical metrics.

Regulatory agencies, professional societies, academic community, NGOs, and industry are involved in developing and validating standard guidelines for toxicity testing strategies of nanomaterials to preempt and avoid unwanted surprises from intentional or unintentional exposures to nanomaterials $(5,25)$. These methods have to be timely and cost-effective, and have to provide toxicological information for the diversity of nanomaterials.

\section{HUMAN AND ENVIRONMENTAL RISK ASSESSMENT OF NANOMATERIALS}

Risk assessment is the evaluation of scientific information on the hazardous properties of a variety of agents, the dose-response relationship, and the extent of exposure of humans or environmental targets to these agents. The product of risk assessment is a statement about the likelihood of exposed humans and the ecosystem with all its components being harmed and to what degree (risk characterization).

The following key aspects of risk assessment are addressed, as they relate to nanomaterials: a) identification of chemical and physical properties; b) environmental fate; c) environmental detection and analysis; d) human and ecosystem exposure; and e) human and ecosystem effects $(5,22,25,26)$.

a) Identification and characterization of chemical substances and materials is an important first step in assessing their risk. The diversity and complexity of nanomaterials makes chemical identification and characterization more difficult than with other chemicals. A broader spectrum of properties will be needed to sufficiently characterize a given nanomaterial, evaluating the hazard and assess the risk.

b) Fundamental properties concerning the environmental fate of nanomaterials are not well understood. Models used to assess the environmental fate and exposure to conventional chemicals are not applicable to intentionally produced nanomaterials. Depending on the relevance of chemical properties or transformation, new models may have to be developed to provide estimations for new materials. However, a certain amount of reliable experimental data must be acquired before the environmental fate, transport, and multimedia partitioning of nanomaterials can be effectively modelled.

c) The challenge in detecting nanomaterials in the environment is compounded not only by the extremely small size of the particles, but also by their unique physical structure and physico-chemical characteristics. The variety of physical and chemical properties can significantly affect the extraction and analytical techniques that can be used for the analyses of a specific nanomaterial.

There is a range of methods available for measuring nanostructured aerosol number, surface area, and mass concentration, although only a few of these are directly applicable to monitoring exposure to nanostructured aerosols. Maynand et al. (27) have proposed a universal aerosol sampler that would log exposure against aerosol number, surface area and mass concentration simultaneously.

In liquid media, the available technologies for size fractionation and collection of nanoparticle fractions include size-exclusion chromatography, ultrafiltration, and field-flow fractionation (9).

For more definitive analytical data, single-particle analytical techniques can be employed. Single particle laser microscope mass spectrometry (LAMMS) can provide chemical composition data on single particles from a collected fraction (28). Electron microscopy techniques can provide particle size, morphological and chemical composition information for a single nanoparticle (Figure 1).

It will be necessary to monitor products that incorporate nanoparticles and nanofibres throughout their life, from manufacture to disposal, in order to estimate the probability of environmental emissions, particularly from disposal and waste management processes.

d) Human and ecosystem exposure account for a series of events beginning with external mechanisms 
that make a chemical / nanoparticle available for absorption or other mode of entry and ending with the chemical or its metabolite reaching the target organ, depending on the nature of the chemical and route of exposure. There are several tools to assess exposure, including monitoring data, exposure models, and the use of analogous data for the existing chemicals, summarized in the US Environmental Protection Agency Nanotechnology White Paper 2007 (5).

e) Assessing nanomaterial toxicity is extremely complex and multifunctional, and is potentially influenced by a variety of physico-chemical properties of nanoparticles. At the moment, there is a significant gap in our knowledge of the environmental, health and ecological implications associated with nanotechnology. However, an exponential increase in scientific papers over the last five years reflects the ongoing work and the importance of this area (1).

Human and environmental risk assessment of nanomaterials will be the central goal of nanotoxicology in the future. Only through development of a sound evidence base in all aspects of hazard and exposure assessment can we hope to generate an informed and reliable risk assessment of nanoparticles. Risk assessment is of key importance to the insurance industry as well as the regulatory agencies that are responsible for formulating exposure and safety guidelines.

\section{REGULATION OF ENGINEERED NANOMATERIALS IN EUROPE AND USA}

A new European chemicals regulation (REACH) was adopted in December 2006. REACH stands for Registration, Evaluation, Authorization and Restriction of Chemicals. REACH Regulation EC No. 1907/2006 and Directive 2006/121/EC amending Directive $67 / 548 /$ EEC were published in the Official Journal on 30 December 2006. REACH entered into force on 1 June 2007.

Some suggest that REACH's applicability to nanoparticles and nanomaterials is unclear. While it is true that REACH does not specifically mention nanoparticles or nanoscale materials anywhere in its eight hundred plus pages of text, both the restriction and authorization processes can also be applied to substances produced or imported in volumes below one tonne per year. If substances in the nano-scale fall under the scope of $\mathrm{REACH}$, their health and environment properties must therefore be assessed following the provisions of this Regulation. However, the methodologies for identifying hazards and evaluating risks of substances at the nano-scale need to be further refined in years to come. It is important to stress that engineered nanoparticles have to be treated as new substances as defined by REACH, and not as "a refinement of particle size distribution". At present, laboratory guidelines or national chemicals policies do not distinguish between handling nano- or macroparticles.

The US EPA has also suggested that the overall risk approach for conventional chemicals is generally also applicable to nanomaterials (5).

Environmental and health dangers posed by synthetic nanoparticles require that the following actions are taken in the near future: a) establishment of national and international interdisciplinary research centres to study the potential hazards of synthetic nanoparticles; b) establishment of a central information office for the general public; and c) establishment of public dialogue on the opportunities and risks posed by synthetic nanoparticles.

\section{CONCLUDING REMARKS}

According to some estimates, nanotechnology promises to far exceed the impact of the Industrial Revolution and is projected to become a US\$ 1 trillion market by 2015 .

The importance of nanotechnologies to our well being is beyond debate, but its potential adverse impacts need to be studied all the more. Nanotoxicology as a new discipline should make an important contribution to the development of a sustainable and safe nanotechnology.

An improved understanding of the risk factors related to nanomaterials in the human body and the ecosystem will aid future development and exploitation of a variety of nanomaterials.

Issues related to new nanoparticles are in the headlines due to the fear of their escaping into the environment. In fact, we have lived with sub-micron sized particles around us forever. The introduction of man-made versions has just brought to light the fact how little we know about their toxic effects.

Awareness is growing about the need to develop an infrastructure for characterizing and measuring nanomaterials in complex matrices and for developing reference materials, both for calibration of instruments used for assessing exposure and dosimetry, and for benchmarking toxicity tests. 
Public expects that new or emerging technologies meet higher safety requirements than tried and tested technologies. Failure to meet these requirements may result in public fear or even rejection of nanotechnology-based products, which often essentially improve the quality of life of individuals, groups of people, or even nations.

\section{REFERENCES}

1. Oberdorster G, Stone V, Donaldson, K. Toxicology of nanoparticles: A historical perspective. Nanotoxicology 2007;1:2-25.

2. Colvin VL. The potential environmental impact of engineered nanomaterials. Nature Biotechnol 2003;21:1166-70.

3. Action group on erosion, technology and concentration (ETC group). [displayed 23 July 2002]. Available at http://www.etcgroup.org/en/materials/publications. html?id=192

4. The Royal Society; The Royal Academy of Engineering. Nanoscience and nanotechnologies: opportunities and uncertainties. [displayed Jul 2004]. Available at http://www.nanotec.org.uk/finalReport.htm

5. US EPA, Nanotechnology White Paper Science Policy Council, Nanotechnology Workgroup. Report No: EPA 100-B-07-001, 132 pp, Feb 2007 US EPA Nanotechnology White Paper [displayed February 2007] Available at http://es.epa.gov/ncer/nano/ publications/whitepaper12022005.pdf

6. Nel A, Xia T, Madler L, Li N. Toxic ptential of materials at the nanolevel Science 2006;311:622-7.

7. Oberdorster G, Oberdorster E, Oberdorster J. Nanotoxicology: An emerging discipline evolving from studies of ultrafine parciles. Environ Health Perspect 2005;113:823-39.

8. Dreher KL. Health and environmental impact of nanotechnology: Toxicological assessment of manufactured nanoparticles. Toxicol Sci 2004;77:35.

9. Powers KW, Brown SC, Krishna VB, Wasdo SC, Moudgil BM, Roberts SM. Research strategies for safety evaluation of nanomaterials. Part VI. Characterization of nanoscale particles for toxicological evaluation. Toxicol Sci 2006;90:296-303.

10. Maynard AD, Aitken RJ. Assessing exposure to airborne nanomaterials: Current abilities and future requirements. Nanotoxicology 2007;1:26-41.

11. Sweet L, Strohm B. Nanotechnology - Life-cycle risk management. Human Ecol Risk Assess 2006;12:52851.

12. Unfried K, Albrecht C, Klotz LO, Von Mikecz A, Grether-Beck S, Schins RPF. Cellular responses to nanoparticles: Target structures and mechanisms. Nanotoxicology 2007;1:52-72.

13. Zhao Y, Nalwa HS. Nanotoxicology. Stewenson Ranch (CA): American scientific publishers; 2006.

14. Donaldson K, Stone V, Clouter A, Renwick L, MacNee W. Ultrafine particles. Occup Environment Med 2001;58:211-6.

15. Uchino T, Tokunaga H, Ando M, Utsumi H. Quantitative determination of $\mathrm{OH}$ radical generation and its cytotoxicity induced by $\mathrm{TiO}_{2}$-UVA treatment. Toxicol In Vitro 2002;16:629-35.

16. Xia T, Kovochich M, Brant J, Hotze M, Sempf J, Oberley T, Sioutas C, Yeh JI, Wiesner MR, Nel AE. Comparison of the abilities of ambient and manufactured nanoparticles to induce cellular toxicity according to an oxidative stress paradigm. Nano Letters 2006;6:1794-1807.

17. Barlow PG, Clouter-Baker A, Donaldson K, MacCallum J, Stone V. Carbon black nanoparticles induce type II epithelial cells to release chemotaxins for alveolar macrophages. Part Fibre Toxicol 2005;2:11.

18. Fortner JD, Lyon DY, Sayes CM, Boyd AM, Falkner JC, Hotze EM, Alemany LB, Tao YJ, Guo W, Ausman KD, Colvin VL, Hughes JB. C-60 in water: Nanocrystal formation and microbial response. Environ Sci Technol 2005;39:4307-16.

19. Chen Z, Meng HA, Xing GM, Chen CY, Zhao YL, Jia GA, Wang TC, Yuan H, Ye C, Zhao F, Chai ZF, Zhu $\mathrm{CF}$, Fang XH, Ma BC, Wan LJ. Acute toxicological effects of copper nanoparticles in vivo. Toxicol Lett 2006;163:109-20.

20. Federici G, Shaw BJ, Handy RD. Toxicity of titanium dioxide nanoparticles to rainbow trout (Oncorhynchus mykiss): Gill injury, oxidative stress, and other physiological effects. Aquat Toxicol 2007;84:415-30.

21. Donaldson K, Stone V, Tran CL, Kreyling W, Borm PJA. Nanotoxicology. Occup Environ Med 2004;61:727-8.

22. Maynard AD. Nanotechnology: assessing the risks. Nano Today 2006;1:22-3.

23. Maynard AD, Aitken RJ, Butz T, Colvin V, Donaldson K, Oberdorster G, Philbert MA, Ryan J, Seaton A, Stone V, Tinkle SS, Tran L, Walker NJ, Warheit DB. Safe handling of nanotechnology. Nature 2006;444:2679.

24. Borm PJA, Robbins D, Haubold S, Kuhlbusch T, Fissan H, Donaldson K, Schins R, Stone V, Kreyling W, Lademann J, Krutmann J, Warheit D, Oberdorster E. The potential risks of nanomaterials: a review carried out for ECETOC. Part Fibre Toxicol 2006;3:11.

25. Scientific committee on emerging and newly identified health risks (SCENIHR) 2006. [displayed March 2006] Available at http://files.nanobio-raise.org/Downloads/ scenihr.pdf

26. OECD. Current Developments/Activities on the Safety of Manufactured Nanomaterials. [displayed 6 
August 2007] Available at http://appli1.oecd.org/olis/ 2007doc.nsf/43bb6130e5e86e5fc12569fa005d004c/ a2a4a59a1e4c229dc125732f00597959/\$FILE/ JT03230791.PDF

27. Maynard AD, Ku BK, Emery M, Stolzenburg M, McMurry PH. Measuring particle size-dependent physicochemical structure in airborne single walled carbon nanotube agglomerates. J Nanopart Res 2007;9:85-92.

28. McMurry PH. A review of atmospheric aerosol measurements. Atmospheric Environ 2000;34:195999.

29. Warheit DB, Webb TR, Sayes CM, Colvin VL, Reed KL. Pulmonary Instillation Studies with Nanoscale TiO2 Rods and Dots in Rats: Toxicity Is not Dependent upon Particle Size and Surface Area. Toxicol Sci 2007;91:227-36.

USEFUL DATABASES RELATED TO THE FIELD

1. Reviews of Nanotechnology Risks. http://www.nsec. wisc.edu/NanoRisks/NS--RisksReviews.php

2. Nanotechnology Risk Resources http://www.nsec.wisc. edu/NanoRisks/NS--NanoRisks.php

3. United States Regulations http://www.nsec.wisc.edu/ NanoRisks/NS--UnitedStates.php

4. International Regulations http://www.nsec.wisc.edu/ NanoRisks/NS--International.php

5. ICON International council on nanotechnology http:// icon.rice.edu/research.cfm

USEFUL ADDITIONAL REPORTS

1. Australian Safety and Compensation Council. A review of the potential occupational health and safety implications of nanotechnology. Report for the Department of Employment and Workplace Relations. Adelaide: Flinders Consulting, Jul 2006. http://
www.ascc.gov.au/ascc/AboutUs/Publications/ ResearchReports/ResearchReports.htm [displayed Oct 2006].

2. The Royal Society; The Royal Academy of Engineering. Nanoscience and nanotechnologies: opportunities and uncertainties. Jul 2004. http://www.nanotec.org. uk/finalReport.htm [displayed Sep 2006].

3. UK Health and Safety Executive. Nanoparticles: an occupational hygiene review. Report prepared by the Institute of Occupational Medicine for the Health and Safety Executive 2004. Research report 274. http:/www.hse.gov.uk/research/rrhtm/rr274.htm [displayed Sep 2006].

4. Maynard AD; Woodrow Wilson International Center for Scholars. Project on emerging nanotechnologies. Nanotechnology: a research strategy for addressing risk. Jul 2006. http://www.nanotechproject. org/67/7-19-06- nanotechnology-a-researchstrategy-for-addressing-risk [displayed Oct 2006].

5. Australian Government Department of Industry, Tourism and Resources. National Nanotechnology Strategy Taskforce. Report on options for a national nanotechnology strategy. Report to Minister Industry, Tourism and Resources. Jun 2006. http://www. industry.gov.au/content/itrinternet/cmscontent. cfm?objectID = 3E81 1562-B36F-F920$886795079 F 355734$ [displayed Sep 2006].

6. US Department of Health and Human Services. Centers for Disease Control and Prevention. National Institute for Occupational Safety and Health (NIOSH). Approaches to safe nanotechnology: an information exchange with NIOSH. Jul 2006. http://www.cdc. gov/niosh/topics/nanotech/safenano/ [displayed Sep 2006]. 


\section{Izuleček}

\section{NANOTOKSIKOLOGIJA ZA VARNO IN TRAJNOSTNO NANOTEHNOLOGIJO}

Nanomateriali izboljšujejo kvaliteto našega življenja, zato bo njihova uporaba na različnih področjih življenja dramatično narasla. Po nekaterih ocenah bo imela nanotehnologija večji vpliv na družbno kot ga je imela industrijska revolucija. Kot posledica razmaha nanotehnologije se bo povečala poklicna in javna izpostavljenost nanodelcem ter izpostavljenost okolja. Nanodelci, ki nas najbolj zanimajo, so strukture, ki imajo v eni dimenziji manj kot $100 \mathrm{~nm}$, in jih je izdelal človek. Njihove lastnosti se zaradi njihove majhnosti bistveno razlikujejo od lastnosti, ki jih imajo večji delci enake kemijske sestave. Šele v zadnjem času so se začela pojavljati vprašanja in vzpodbujati raziskave o potencialni nevarnosti nanodelcev. Trenutni rezultati toksikoloških študij potrjujejo kvarne učinke nanodelcev in navajajo, da nanodelci najverjetneje delujejo na organizem preko oksidativnega stresa. Študije nakazujejo številne posebnosti nanodelcev pri interakcijah s celicami, tkivi in organizmi. Najverjetneje je ta trenutek pomembno pridobiti čim več ustreznega znanja za oblikovanje regulative na področju varne proizvodnje in uporabe nanodelcev. Namen prispevka je povzeti že znana dejstva o nanodelcih in predstaviti naloge nove smeri v toksikologiji, nanotoksikologije. V prispevku je povzeta najnovejša regulativa na področju ugotavljanja in zagotavljanja varnosti proizvodov nanotehnologij, navedene so nekatere koristne baze podatkov, razprave ter nacionalne in mednarodne smernice na področju nanotehnologije.

KLJUČNE BESEDE: elektronska mikroskopija, ocena tveganja, proizvedeni nanodelci, testiranje strupenosti

\section{CORRESPONDING AUTHOR:}

Damjana Drobne, Ph.D.

Department of Biology, University of Ljubljana

Večna pot 111, SI-1000 Ljubljana, Slovenia

E-mail: damjana.drobne@bf.uni-lj.si 